\title{
Optical and structural properties of highly porous shell structured Fe doped $\mathrm{TiO}_{2}$ thin films
}

\author{
C. S. Naveen*, P. Raghu, H. M. Mahesh, \\ K. Narasimha Rao, R. Rakesh Kumar, \\ A. R. Phani
}

Received: 21 June 2013/Revised: 11 September 2013/Accepted: 23 January 2014/Published online: 18 March 2014

(C) The Nonferrous Metals Society of China and Springer-Verlag Berlin Heidelberg 2014

\begin{abstract}
TiO}_{2}$ thin films with $0.2 \mathrm{wt} \%, 0.4 \mathrm{wt} \%, 0.6$ wt $\%$, and $0.8 \mathrm{wt} \% \mathrm{Fe}$ were prepared on glass and silicon substrates using sol-gel spin coating technique. The optical cut-off points are increasingly red-shifted and the absorption edge is shifted over the higher wavelength region with $\mathrm{Fe}$ content increasing. As Fe content increases, the optical band gap decreases from 3.03 to $2.48 \mathrm{eV}$ whereas the tail width increases from 0.26 to $1.43 \mathrm{eV}$. The $\mathrm{X}$-ray diffraction (XRD) patterns for doped films at $0.2 \mathrm{wt} \%$ and $0.8 \mathrm{wt} \% \mathrm{Fe}$ reveal no characteristic peaks, indicating that the film is amorphous whereas undoped $\mathrm{TiO}_{2}$ exhibits (101) orientation with anatase phase. Thin films of higher Fe content exhibit a homogeneous, uniform, and nanostructured highly porous shell morphology.
\end{abstract}

Keywords $\mathrm{Fe} ; \mathrm{TiO}_{2}$; Porous shell; Sol-gel

\section{Introduction}

The studies on nano-structured wide gap oxide semiconductor thin films attract many researchers due to their distinctive properties such as tailored band gap, with

C. S. Naveen*, P. Raghu, H. M. Mahesh

Department of Electronic Science, Bangalore University, Jnanabharathi, Bangalore 560056, Karnataka, India

e-mail: csnaveen@live.com

K. Narasimha Rao, R. Rakesh Kumar

Department of Instrumentation and Applied Physics, Indian

Institute of Science, Bangalore 560012, Karnataka, India

A. R. Phani

Nano-Research for Advanced Materials and Technologies,

(Nano-RAM Technologies), Bangalore 560040, Karnataka, India doping, high transparency, and high dielectric constant. These thin films have wide range of applications in protective and antireflective coatings [1,2], gas sensors [3], thin film capacitors [4], solar collectors and solar cells [5], and inductive devices [6]. Investigations are carried out by several researchers to enhance the optical transmittance with modified parameters of $\mathrm{TiO}_{2}$ by doping with transition metal ions such as $\mathrm{Fe}, \mathrm{Nb}, \mathrm{Mn}, \mathrm{Co}, \mathrm{Sn}, \mathrm{Cd}$, and Ni. Among a range of dopant, replacement of iron in the titania model is ideal due to similar size of $\mathrm{Fe}^{3+}$ and $\mathrm{Ti}^{4+}$. It is an observed fact that, though iron always presents in titanium oxide as an intrinsic impurity, the electrical and optical properties of $\mathrm{TiO}_{2}$ depend on the concentrations of both intrinsic defects and extrinsic impurities [7]. Oxide films are deposited both by physical (evaporation, sputtering, ion beam) and chemical (chemical vapor deposition, plasma enhanced chemical vapor deposition, spray pyrolysis, and sol-gel) methods [8-10]. Over these deposition methods, sol-gel based spin coating is preferred due to its ease of coating procedure and synthesis. In the present study, effect of $\mathrm{Fe}$ doping in $\mathrm{TiO}_{2}$ on optical, structural, and morphological properties prepared by solgel spin coating on a glass substrate was investigated.

\section{Experimental}

\subsection{Sample preparation}

Titanium iso-propoxide (Sigma-Aldrich) with purity of $99.99 \%$ and ferric chloride salt (Merck $\geq 98 \%$ ) were used as the starting materials for the synthesis of solgel. The systematic process flow of solution preparation is shown in Fig. 1. The substrates used for deposition were degreased in soap water, then ultrasonically cleaned with acetone and 


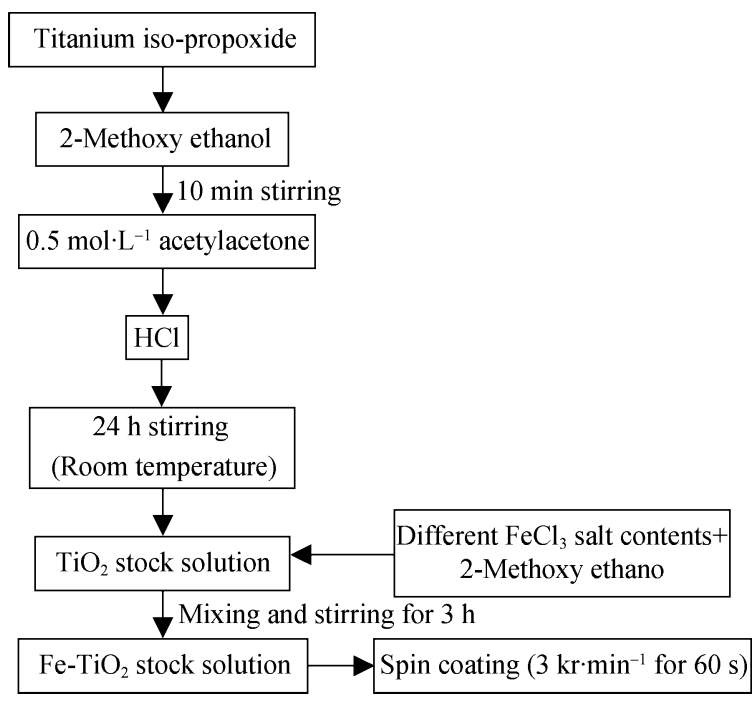

Fig. 1 Process flowchart for preparation and deposition of $\mathrm{Fe}-\mathrm{TiO}_{2}$ thin films

dried in oven at $100{ }^{\circ} \mathrm{C}$ for $15 \mathrm{~min}$. The films were deposited by spin coating at $3,000 \mathrm{r} \cdot \mathrm{min}^{-1}$ for $60 \mathrm{~s}$. In order to increase the thickness, multiple spin was employed between successive depositions; the films were preheated at $80{ }^{\circ} \mathrm{C}$ for $15 \mathrm{~min}$. Finally, obtained thin films were annealed at 200,400 , and $800{ }^{\circ} \mathrm{C}$ for $3 \mathrm{~h} /$ air ambient.

\subsection{Characterization}

The optical properties of $\mathrm{Fe}$ doped $\mathrm{TiO}_{2}$ films were determined by visible-near infrared spectrophotometer (Ocean Optics, USA). The thickness and refractive index were calculated using transmission spectra by envelope technique [11]. The optical band gap was obtained using Tauc's equation $[12,13]$ and difference in band gap with respect to doping was determined by extra plotting $(\alpha h v)^{1 / 2}$ versus $(h v)$. The structural properties of the films were investigated using a Philips X-ray diffractometer (XRD) with monochromatic $\mathrm{Cu} \mathrm{K} \alpha$ radiation. The film morphology was studied using scanning electron microscopy (SEM, Raith, eLiNE).

\section{Results and discussion}

\subsection{Optical properties}

The optical properties were studied using optical transmission and reflection spectra in the visible wavelength (350-800 nm) for the films annealed at $400{ }^{\circ} \mathrm{C}$ on glass substrates. The optical parameters such as refractive index, absorption coefficient, band gap were analyzed from the

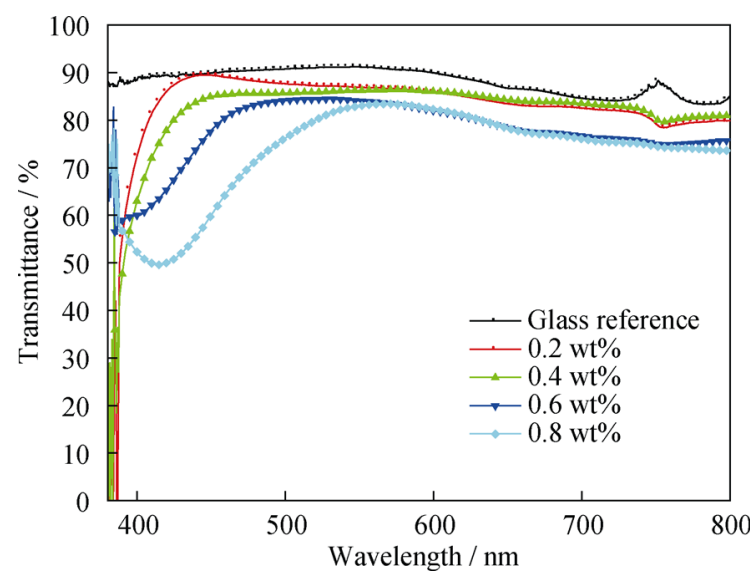

Fig. 2 Spectral transmittance of $\mathrm{Fe}-\mathrm{TiO}_{2}$ thin films annealed at $400{ }^{\circ} \mathrm{C} / 3 \mathrm{~h}$ /air ambient

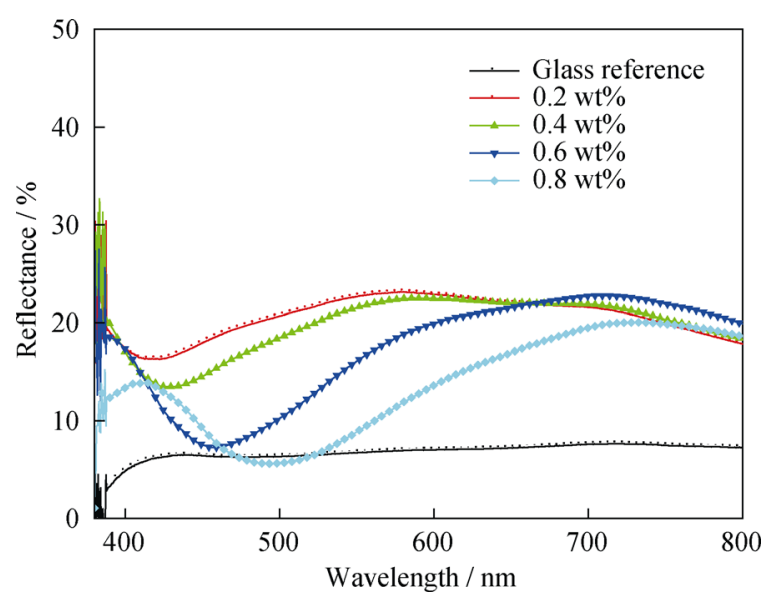

Fig. 3 Spectral reflectance of $\mathrm{Fe}-\mathrm{TiO}_{2}$ thin films annealed at $400{ }^{\circ} \mathrm{C} /$ $3 \mathrm{~h} / \mathrm{air}$ ambient

transmission spectra. The maximum thickness obtained by envelope technique for three multiple coatings is found to be $260 \mathrm{~nm}$. The transmittance spectra of $\mathrm{Fe}-\mathrm{TiO}_{2}$ with different Fe contents on glass substrate are shown in Fig. 2. The spectra reveals that the formation of absorption edge toward higher wavelength region is up to $418 \mathrm{~nm}$ (Fig. 3), whereas in pure $\mathrm{TiO}_{2}$ thin films transmittance quickly decreases below $355 \mathrm{~nm}$ indicating the absorption of light induced by the excitation of electrons from the valence band to the conduction band [14]. The $0.2 \mathrm{wt} \%$ Fe film exhibits high transmittance $(85 \%)$ in visible wavelength and then decreases with consecutive increase in doping concentration. The shift in the transmission edge as doping increases indicates the decrease in band gap of the film. The refractive index of doped $\mathrm{TiO}_{2}$ thin films is found to be in the range of $2.05 \mathrm{wt} \%-1.95 \mathrm{wt} \%$ for $0.2 \mathrm{wt} \%-0.8 \mathrm{wt} \%$ estimated for half wavelength. Further, the Fe doped $\mathrm{TiO}_{2}$ thin films are fully 


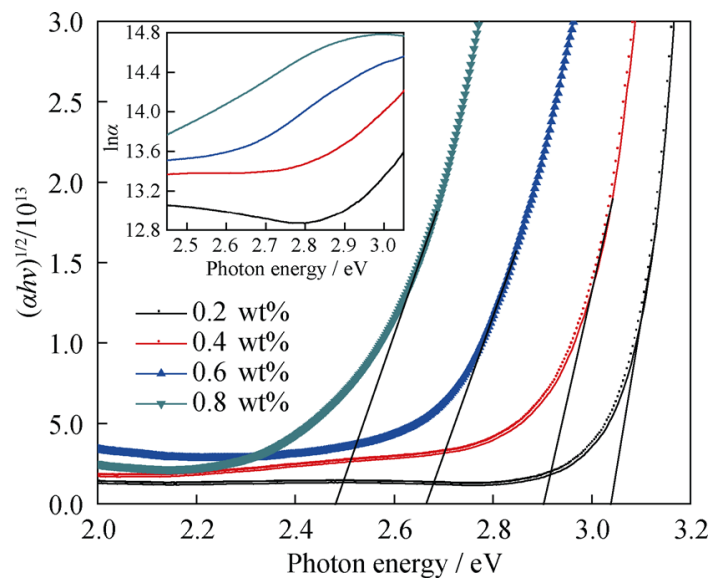

Fig. 4 Band gap of $\mathrm{Fe}-\mathrm{TiO}_{2}$ thin films (Inset variation of $\ln \alpha$ vs $h v$ )

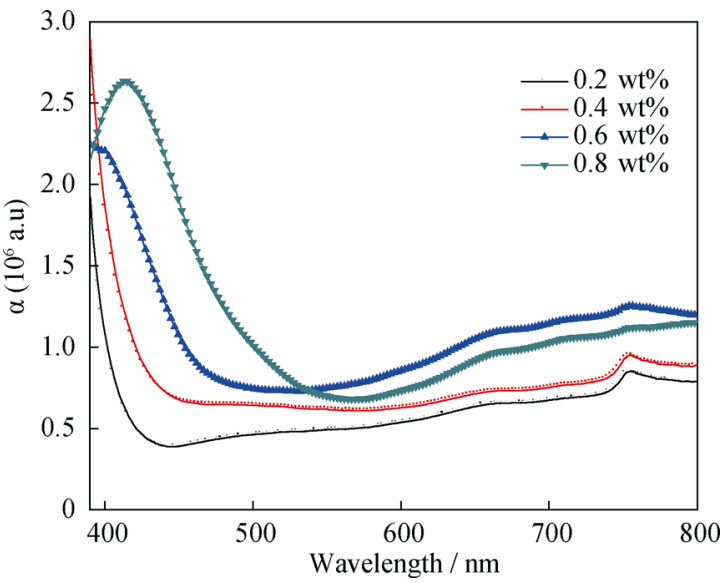

Fig. 5 Absorption coefficient of $\mathrm{Fe}-\mathrm{TiO}_{2}$ thin films with respect to wavelength

transparent and exhibit distinctive scattering transmittance for the thin films in the visible wavelength. This effect was previously observed by Kim et al. [15].

Figure 4 represents the reflectance properties of $\mathrm{Fe}$ doped $\mathrm{TiO}_{2}$ thin films. It can be noticed that the reflectance is increasingly red-shifted with the increase of doping content. This can be attributed to the charge shift which can be induced between the different valence states of same metal, such as between $\mathrm{Fe}^{2+}$ and $\mathrm{Fe}^{3+}$. Absorptions owing to charge transfer are the main cause of the red color of iron oxides and hydroxides where it is found that the absorption bands rapidly decrease in intensity [16]. Reflectance spectra of iron oxides have such strong absorption bands that the shape changes significantly with grain size. Small shifts in absorption band position are also observed due to substitution of other elements, like aluminum for iron in hematite [17]. The minimum reflectance
Table 1 Measured values of band gap and tail width of different Fe contents doped $\mathrm{TiO}_{2}$ thin films

\begin{tabular}{lll}
\hline Fe content/wt $\%$ & Band gap/eV & Tail width/eV \\
\hline 0.2 & 3.03 & 0.26 \\
0.4 & 2.90 & 0.75 \\
0.6 & 2.66 & 0.88 \\
0.8 & 2.48 & 1.43 \\
\hline
\end{tabular}

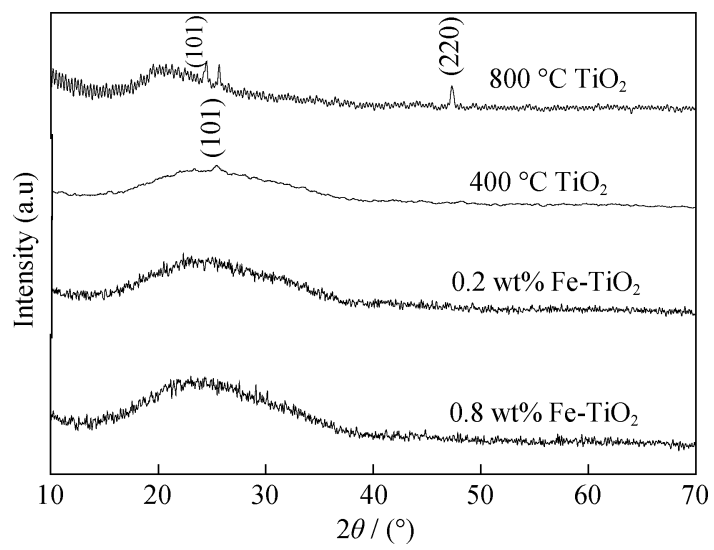

Fig. 6 XRD patterns of pure $\mathrm{TiO}_{2}$ and $\mathrm{Fe}$ doped $\mathrm{TiO}_{2}$ thin films

is equal to glass reflectance exhibited by thin films of greater than $0.4 \mathrm{wt} \% \mathrm{Fe}$ doping content. The minimum reflectance can be attributed to the transformation in morphology toward porous shell. The porous morphology also helps to obtain the minimum reflection due to total internal reflection of light [18].

The optical band gap of the $\mathrm{Fe}-\mathrm{TiO}_{2}$ thin films was estimated by the extrapolation of the linear portion of the $(\alpha h v)^{1 / 2}$ versus $h v$ plots using the relation,

$\alpha h v=A\left(h v-E_{\mathrm{g}}\right)^{1 / 2}$

where $h v$ is the photon energy, $\alpha$ is absorption coefficient, $E_{\mathrm{g}}$ is the band gap and $A$ is the frequency independent constant. The optical band of $\mathrm{Fe}-\mathrm{TiO}_{2}$ varies depending on the variation of $\mathrm{Fe}$ concentration. The measured optical band gap values of the doped $\mathrm{TiO}_{2}$ films are between 2.48 and $3.03 \mathrm{eV}$ for $0.8 \mathrm{wt} \%$ and $0.2 \mathrm{wt} \% \mathrm{Fe}$ doping, respectively (Fig. 5). The inset of Fig. 5 represents the Urbach tail which signifies the characteristic phenomena of absorption curve with respect to photon energy. If the structure of the film is disorder, it can be estimated the level of disorderness using this Urbach energy [19] which results in lean-in the transmittance spectra toward minimum photon energy. The tail width of the films can be calculated by the slope of the straight line portion of the plot. The optical band gap $\left(E_{\mathrm{g}}\right)$ and the tail width $(\Delta E)$ of doped $\mathrm{TiO}_{2}$ films are shown in Table 1 . The tail width 

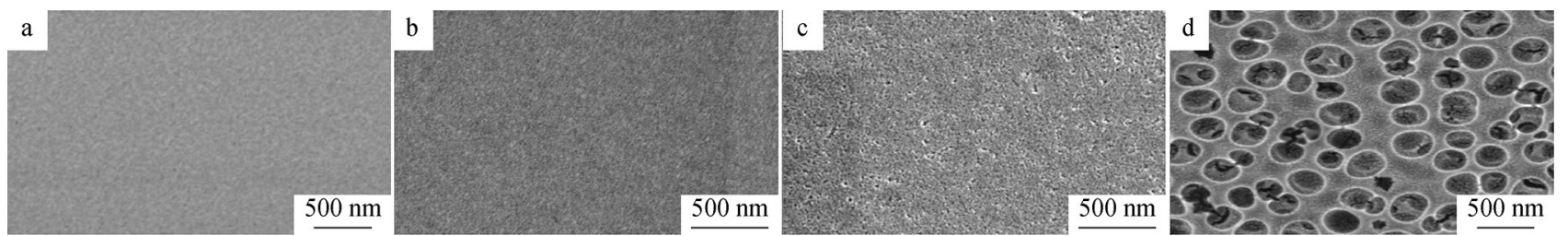

Fig. 7 SEM images of $\mathrm{Fe}-\mathrm{TiO}_{2}$ thin film with different $\mathrm{Fe}$ contents: a $0.2 \mathrm{wt} \%$, b $0.4 \mathrm{wt} \%$, c 0.6 wt $\%$, and d 0.8 wt $\%$

increases with doping content from 0.26 to $1.43 \mathrm{eV}$. This increase in tail width is the evidence for the change in crystalline to amorphous porous form of the prepared films with decreased band gap.

\subsection{Structural properties}

The XRD spectra of pure and doped $\mathrm{TiO}_{2}$ thin films are shown in Fig. 6. The pure and doped $\mathrm{TiO}_{2}$ and films were annealed at different elevated $\left(200-800{ }^{\circ} \mathrm{C}\right)$ temperatures. $\mathrm{TiO}_{2}$ film exhibits amorphous nature as there are no characteristic peaks when annealed at $200{ }^{\circ} \mathrm{C}$. As the annealing temperature further increases to 400 and $800{ }^{\circ} \mathrm{C}$, the eminent peak at $2 \theta$ value of $25.33^{\circ}$ is obtained corresponding to (101) orientation of the crystalline anatase phase (JCPDS card number 83-2243) and an additional peak at $2 \theta$ value of $36.11^{\circ}$ corresponding to (101) orientation of the rutile phase (JCPDS 88-1175), respectively. The grain size calculated using Scherrer's equation for $\mathrm{TiO}_{2}$ films is found to be $14 \mathrm{~nm}$. The XRD patterns for doped films at $0.2 \mathrm{wt} \%$ and $0.8 \mathrm{wt} \%$ Fe doping annealed at $400{ }^{\circ} \mathrm{C}$ reveal no characteristic peaks, indicating that the film is amorphous. This occurrence caused by the iron doping can dwell in the crystallization of anatase $\mathrm{TiO}_{2}$. Wang et al. [20] reported that doping of higher concentration of $\mathrm{Fe}$ will inhibit the crystallization of $\mathrm{TiO}_{2}$. Even though reported value indicates that $\mathrm{Fe}^{3+}$ doped $\mathrm{TiO}_{2}$ speeds up anatase transformation to rutile and reduces the initial transition temperature to below $550{ }^{\circ} \mathrm{C}$ [21] but in this investigation, the crystallization of $\mathrm{TiO}_{2}$ is not found for doped $\mathrm{TiO}_{2}$ thin films calcined at $400{ }^{\circ} \mathrm{C}$ for $3 \mathrm{~h}$. This suggests that the inhibition of phase transition is not only by higher doping concentration but also with the change in morphology which is depicted in Fig. 6.

\subsection{Surface morphology}

Surface morphology of $0.2 \mathrm{wt} \%, 0.4 \mathrm{wt} \%, 0.6 \mathrm{wt} \%$, and $0.8 \mathrm{wt} \% \mathrm{Fe}$ doped $\mathrm{TiO}_{2}$ thin films are shown in Fig. 7. The $0.2 \mathrm{wt} \% \mathrm{Fe}-\mathrm{TiO}_{2}$ thin film exhibits uniform, dense, and compact morphology. The further doping of Fe causes change in morphology from smooth surface to porous shell. The $0.8 \mathrm{wt} \%$ film has the porosity ranging from 100 to $500 \mathrm{~nm}$.

\section{Conclusion}

The increase of the iron content in $\mathrm{TiO}_{2}$ causes change in structural and morphology of the films. The inhibition in crystallinity is noticed for doped thin films. This is evident from the increased tail width with decreased band gap value. Surface morphology shows the change in highly dense uniform to porous nano-shell structure with the increase of $\mathrm{Fe}$ content. Even at higher concentrations, the thin films remain transparent. The results indicate that the low reflectance with porous morphology thin films is well suited for gas sensors and antireflective thin films.

Acknowledgments Authors are thankful to Centre for Nano Science and Engineering, IISc, Bangalore for providing the characterization facility.

\section{References}

[1] Narasimha Rao K. Influence of deposition parameters on optical properties of $\mathrm{TiO}_{2}$ films. Opt Eng SPIE. 2002;41(9):2357.

[2] Phani AR, Gammel FJ, Hack T. Structural, mechanical and corrosion resistance properties of $\mathrm{Al}_{2} \mathrm{O}_{3}-\mathrm{CeO}_{2}$ nanocomposites in silica matrix on $\mathrm{Mg}$ alloys by a sol-gel dip coating technique. Surf Coat Technol. 2006;201(6):3299.

[3] Tang H, Prasad K, Sanjines R, Levy F. $\mathrm{TiO}_{2}$ anatase thin films as gas sensors. Sens Actuators B. 1995;26(1-3):71.

[4] Prasad K, Bally AR, Schmidt PE, Levy F, Benoit J, Barthou C, Benalloul P. Ce doped $\mathrm{TiO}_{2}$ insulators in thin film electroluminescent devices. Jpn J Appl Phys. 1997;36(9A):5696.

[5] Hauffe K, Danzmann HJ, Pusch H, Range J, Volz H. New experiments on the sensitization of zinc oxide by means of the electrochemical cell technique. J Electrochem Soc. 1970;117(8):993.

[6] Zhou XY, Yao DS. Fabrication and magnetic properties of NiFe-ZnO nano-granular films. Rare Met. 2013;32(3):269.

[7] Bally AR, Korobeinikova EN, Schmid PE, Levy F, Bussy F. Structural and electrical properties of Fe-doped $\mathrm{TiO}_{2}$ thin films. J Phys D. 1998;31(10):1149.

[8] Hu L, Yoko T, Kozuka H, Sakka S. Effects of solvent properties of solgel derived $\mathrm{TiO}_{2}$ coating films. Thin Solid Films. 1992;219(1-2): 18 .

[9] Aarik J, Aidla A, Kiisler A-A, Uustare T, Sammelselg V. Effect of crystal structure on optical properties of $\mathrm{TiO}_{2}$ films grown by atomic layer deposition. Thin Solid Films. 1997;305(1-2):270.

[10] Beganskiene A, Sakirzanovas S, Melninkaitis A, Sirutkaitis V, Kareiva A. Solgel derived optical coating with controlled parameters. Mater Sci. 2006;12(4):283.

[11] Swanepoel R. Determination of the thickness and optical constants of amorphous silicon. J Phys E. 1983;16(12):1214. 
[12] NarasimhaRao K, Vishwas M, Sharma SK, Arjuna Gowda KV. Some studies on $\mathrm{TiO}_{2}$ films deposited by sol-gel technique, In: Proceedings of SPIE Bellingham WA, San Diego; 2008. 7067.

[13] Chrysicopoulou P, Davazoglou D, Trapalis Chr, Kordas G. Optical properties of very thin $(<100 \mathrm{~nm})$ sol-gel $\mathrm{TiO}_{2}$ films. Thin Solid Films. 1998;323(1-2):188.

[14] Viswas M, Sudhir Kumar Sharma, Narasimha Rao K, Mohan S, Arujna Gowda KV, Chakradhar RPS. Influence of surfactant and annealing temperature on optical properties of sol-gel derived nano-crystalline $\mathrm{TiO}_{2}$ thin films. Spectrochim Acta Part A. 2010;75(3):1073.

[15] Kim NJ, La YH, Im SH, Ryu BK. Optical and structural properties of $\mathrm{Fe}-\mathrm{TiO}_{2}$ thin films prepared by sol-gel dip coating. Thin Solid Films. 2010;518(24):e156.

[16] Kim DH, Hong HS, Kim SJ, Song JS, Lee KS. Photocatalytic behaviors and structural characterization of nanocrystalline $\mathrm{Fe}$ doped $\mathrm{TiO}_{2}$ synthesized by mechanical alloying. J Alloy Compd. 2004;375(1-2):259.
[17] Morris RV, Laucer HV, Lawson CA, Gibson EK, Nace GA, Stewart C. Spectral and other physicochemical properties of submicron powders of hematite $\left(\alpha-\mathrm{Fe}_{2} \mathrm{O}_{3}\right)$, maghemite $(\gamma$ $\left.\mathrm{Fe}_{2} \mathrm{O}_{3}\right)$, goethite $(\alpha-\mathrm{FeOOH})$, and lepidocrocite $(\gamma-\mathrm{FeOOH})$. J Geophys Res. 1985;90(B4):3126.

[18] Zolotarev VM, Perveev AF, Arkatova TG, Muranova GA. A study of microporous $\mathrm{SiO}_{2}$ films by perturbed total internal reflection. J Appl Spectrosc. 1972;16(2):248.

[19] Urbach F. The long-wavelength edge of photographic sensitivity and of the electronic absorption of solids. Phys Rev. 1953;92(5): 1324.

[20] Wang MC, Lin HJ, Yang TS. Characteristics and optical properties of iron ion $\left(\mathrm{Fe}^{3+}\right)$-doped titanium oxide thin films prepared by a sol-gel spin coating. J Alloy Compd. 2009;473(1-2): 394.

[21] Tonejc AM, Djerdj I, Tonejc A. Evidence from HRTEM image processing, XRD and EDS on nano-crystalline iron-doped titanium oxide powders. Mater Sci Eng B. 2001;85(1):55. 